\title{
Telaah Kritis Terhadap Upaya Peningkatan Literasi Keuangan Melalui Tabungan Sekolah
}

\author{
Muhammad Rifqi Hidayat ${ }^{*}$, Rusdiana ${ }^{2}$ \\ 1,2 Universitas Islam Negeri Antasari, Banjarmasin - Indonesia
}

\section{A R T I C L E I N F O}

Article history:

Received April, 252021

Received in revised form May, 292021

Accepted June, 62021

Available online June, 28 2020

Kata Kunci:

Literasi keuangan, siswa sekolah dasar, tabungan sekolah.

Keywords:

Elementary students,

financial literacy, school's saving.

\begin{abstract}
A B S T R A K
Tujuan dari penelitian ini adalah untuk menganalisa pelaksanaan upaya peningkatan literasi keuangan melalui tabungan siswa pada siswa tingkat sekolah dasar di kota Banjarmasin, dan merumuskan konsep tabungan siswa yang ideal untuk memaksimalkan hasil dari upaya peningkatan literasi keuangan tersebut. Penelitian ini merupakan riset kualitatif lapangan yang disertai dengan survey kuantitatif kepada 412 responden dari 18 sekolah yang berbeda mengenai perilaku menabung siswa, untuk dianalisa secara deskriptif. Hasil penelitian menunjukkan bahwa hanya $38,1 \%$ responden yang mengalokasikan sebagian uang sakunya untuk ditabung secara mandiri. Sebanyak 11 dari 18 sekolah yang menjadi lokasi riset mengelola tabungan siswanya secara mandiri dengan metode pencatatan manual melalui buku tabungan atau Microsoft Excel. Tujuh sekolah lainnya telah melakukan kerjasama dengan lembaga perbankan, namun bank hanya mampu berkunjung satu hingga dua kali per minggunya. Maka orang tua siswa perlu mendapatkan pemahaman yang baik mengenai cara mengajarkan anaknya untuk menabung. Pencatatan tabungan siswa seyogyanya ditunjang oleh sistem berbasis web yang dapat dipantau oleh guru, siswa, dan wali muridnya. Sekolah juga sebaiknya tetap menerima setoran tabungan siswa setiap harinya dengan pencatatan mandiri, untuk kemudian disetorkan sekaligus pada saat bank melakukan kunjungan ke sekolah.
\end{abstract}

\section{A B S T R A C T}

The purpose of this study is to analyze how the implementation of efforts to increase financial literacy through student savings at elementary school level students in the city of Banjarmasin, as well as to formulate an ideal student savings concept to maximize the results of efforts to increase financial literacy. This research is qualitative field research accompanied by a quantitative survey to 412 respondens from 18 different schools of students' saving behavior, which then will be analyzed descriptively. The results showed that only $38.1 \%$ of respondents independently allocated a portion of their allowance for savings. 11 of the 18 schools that become research sites manage their student savings independently with manual recording via a passbook or Microsoft Excel. Seven other schools have collaborated with banking institutions, but banks are only able to visit one to two times per week. Thus, parents of students need to have a good understanding of how to teach their children to save. The recording of student savings should also be supported by a web-based system that can be monitored by the teacher, students, and student guardians. Schools should also continue to receive student savings deposits every day with independent registration, to then be deposited at the same time when the bank visits the school.

\footnotetext{
* Corresponding author.

E-mail : rifqifebi@uin-antasari.ac.id (Muhammad Rifqi Hidayat)
} 


\section{Pendahuluan}

Aktivitas ekonomi adalah bagian yang selalu ada dalam kegiatan sehari-hari, oleh karena itu, pendidikan mengenai ekonomi dan keuangan tersebut, atau yang biasa dikenal dengan istilah literasi keuangan, harus diberikan kepada setiap orang sejak dini. Seiring dengan bertambahnya umur seseorang, maka kebutuhan serta keinginan yang harus ia penuhi pun akan selalu bertambah dan tak terbatas, sedangkan sumber daya yang dimiliki untuk memenuhi seluruh kebutuhan tersebut terbatas, oleh karena itu diperlukan kemampuan untuk mengambil keputusan yang rasional, efisien, dan bernilai manfaat dalam mengarahkan sumber daya yang ada. Kemampuan semacam ini hanya bisa diperoleh melalui literasi ekonomi yang mumpuni, baik yang bersumber dari pendidikan keluarga, sekolah, maupun lingkungan (Hambali, 2016, hlm. 42).

Berbagai investasi bodong yang banyak memakan korban merupakan akibat dari kurangnya kesadaran serta pengetahuan dan pemahaman tentang keuangan (Wijayanti, Agustin, \& Rahmawati, 2016, hlm. 88). Terbukti misalnya pada kasus Dimas Kanjeng Taat Pribadi yang terjadi tahun 2016 silam, dimana menurut laporan BBC.com berhasil menipu ribuan orang dari berbagai profesi termasuk akademisi dan politikus karena ia mengaku mampu menggandakan uang. Masyarakat yang tertipu umumnya terperdaya dengan keinginan untuk mendapatkan kekayaan dalam waktu singkat, sehingga pemikirannya menjadi tidak rasional (Affan, 2016).

Sebelum kasus Dimas Kanjeng Taat Pribadi tersebut, tahun 2012 sempat pula terjadi kasus penipuan yang dilakukan oleh Koperasi Langit Biru di Cianjur. Koperasi ini menjanjikan keuntungan yang tidak masuk akal, yaitu bahwa cukup dengan modal satu hingga lima juta saja, akan mendapatkan keuntungan seratus persen setelah satu bulan. Padahal menurut Syarifudin Hasan selaku Menteri Koperasi dan UKM saat itu sebagaimana dilansir oleh merdeka.com, investasi yang aman indikator keuntungannya adalah suku bunga acuan yang pada bulan tersebut hanya sebesar 5,75\% (Mohamad, 2012). Sekitar seratus empat puluh ribu nasabah telah berinvestasi di koperasi tersebut dengan total dana yang terkumpul puluhan miliar rupiah (detiknews, 2012).

Kedua contoh di atas menunjukkan bahwa pemahaman yang rendah terhadap ekonomi akan memperbesar peluang seseorang untuk jatuh ke dalam penipuan baik dalam bentuk investasi bodong ataupun penipuan lainnya. Kesimpulan ini juga didukung oleh penelitian yang dilakukan oleh Laily bahwa tingkat literasi keuangan berpengaruh terhadap perilaku keuangan seseorang (Laily, 2016). Apalagi berdasarkan penelitian dari Astuti ditemukan bahwa ibu rumah tangga yang menjadi subjek penelitiannya cenderung melakukan pembelian barang yang bersifat konsumtif hanya atas dasar suka dan tertarik terhadap model barang tanpa disertai dengan perencanaan maupun pertimbangan atas kemanfaatan dan kegunaan barang tersebut (Astuti, 2013, hlm. 152). Padahal, sikap konsumtif seperti ini jika dilakukan terusmenerus maka akan berpotensi merugikan diri sendiri maupun orang lain (Putri, 2017, hlm. 102).

Berdasarkan fakta-fakta di atas, maka dapat disimpulkan bahwa literasi ekonomi sangat penting untuk mendidik setiap orang agar mampu bersikap arif dan bijak dalam mengelola keuangan agar bisa terarah dengan benar, sehingga ia tidak akan terjebak dalam pola hidup konsumtif, dan tidak pula terjatuh kepada berbagai penipuan yang marak terjadi. Herawati menyebutkan bahwa pemahaman akan pengetahuan pengelolaan keuangan yang baik mulai dikenalkan sejak dini, bahkan pada usia pra sekolah dan sekolah dasar, untuk membiasakan anak agar dapat mengelola keuangannya dengan tepat sehingga ketika mencapai usia dewasa dapat menerapkannya dengan mudah (Herawati, 2015, hlm. 62).

Mengenai hal ini, Allah mengingatkan kepada para orang tua dalam al-Qur'an agar tidak membiarkan keturunannya dalam keadaan yang lemah akibat kesalahan orang tua dalam mengelola hartanya (Sriono, 2017, hlm. 116). sebagaimana disebutkan dalam surah an-Nisa ayat 9 yang berbunyi:

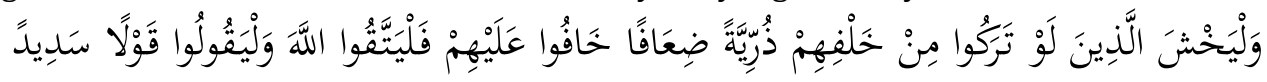

Artinya: "Dan hendaklah takut kepada Allah orang-orang yang seandainya meninggalkan di belakang mereka anak-anak yang lemah, yang mereka khawatir terhadap (kesejahteraan) mereka. Oleh sebab itu hendaklah mereka bertakwa kepada Allah dan hendaklah mereka mengucapkan perkataan yang benar."

Sayangnya, pendidikan literasi keuangan ini di Indonesia masih jarang dilakukan. Bahkan pembicaraan tentang uang di hadapan anak merupakan hal yang tabu dan harus dihindari, sehingga muncul anggapan bahwa literasi keuangan bukanlah termasuk bagian dari life skill yang harus dimiliki oleh seorang anak (Rapih, 2016, hlm. 14-16). Hal ini terbukti dengan tidak adanya mata pelajaran yang memberikan wawasan dan kecakapan mengenai kesehatan finansial keluarga dalam kurikulum pendidikan dasar maupun menengah.

Menyikapi permasalahan ini, Otoritas Jasa Keuangan (OJK) selaku regulator keuangan di Indonesia menawarkan program tabungan anak sebagai solusi untuk memberikan edukasi keuangan kepada anak 
Indonesia dalam produk tabungan bernama Simpanan Pelajar (SimPel). SimPel (SimPel iB untuk bank syariah) bertujuan untuk menumbuhkan budaya menabung sejak dini (Ma'ruf, Zulfiah Larisu, \& La Iba, 2017), sekaligus untuk meningkatkan literasi dan inklusi keuangan anak Indonesia. Berdasarkan laporan OJK pada triwulan I 2018, program tabungan SimPel telah didukung oleh 280 bank. Adapun total jumlah rekening yang telah diterbitkan sejumlah 10.990 .889 rekening dengan total transaksi sebesar 2,51 Triliun Rupiah, dan sudah ada 214.354 sekolah yang bekerjasama dengan lembaga perbankan tersebut. Produk tabungan SimPel diluncurkan tanggal 8 September 2015 sebagai bentuk pelaksanaan program Strategi Nasional Lembaga Keuangan Inklusif (SNLKI) yang dicanangkan Presiden pada tanggal 14 Juni 2015.

Terlepas dari program 0JK tersebut, sejumlah sekolah dasar secara mandiri juga membuka fasilitas tabungan kepada para siswanya, untuk turut andil dalam meningkatkan literasi keuangan kepada generasi muda. Sayangnya, tabungan siswa yang dikelola secara mandiri ini malah menimbulkan persoalan baru, khususnya apabila pencatatannya masih dilaksanakan secara manual. Bulan Mei 2020 lalu misalnya, seorang oknum guru Sekolah Dasar Negeri (SDN) 1 Banjaratma menggunakan uang tabungan siswanya untuk kepentingan pribadi, dan tertangkap saat berupaya membobol ruko karena terdesak harus mengembalikan tabungan tersebut (Suripto, 2020).

Berikutnya di tingkat pendidikan yang lebih tinggi, kasus Rosita yang terjadi di tahun 2017 dapat dijadikan ibrah mengenai permasalahan ini. Murid kelas 9 Madrasah Tsanawiyah (MTS) Negeri 1 Tumpang ini mengklaim bahwa dirinya telah menabung di sekolah hingga mencapai lebih dari 42 juta Rupiah, namun saat uang tersebut hendak diambil, sekolah yang dalam hal ini diwakili oleh wali kelas tidak mengakui tabungan Rosita tersebut. Menurut catatan sekolah, tabungan Rosita hanya berjumlah 135 ribu Rupiah, sedangkan Rosita dan keluarganya memiliki pembukuan tersendiri dan tercatat bahwa tabungannya memang sebesar 42 juta Rupiah. Hal ini membuat Rosita panik hingga mencoba bunuh diri dengan meminum beberapa butir pil obat sakit kepala dicampur minuman bersoda, sebab uang tabungan tersebut berasal dari pemberian orang tuanya (Aminudin, 2017).

Kedua kasus di atas menjadi bukti bahwa upaya peningkatan literasi keuangan di lingkungan sekolah dalam bentuk tabungan siswa ternyata tidak tepat sasaran dan bahkan dapat memicu masalah lain jika teknisnya tidak ditangani dengan benar. Sistem pencatatan tabungan sekolah yang umumnya masih dikerjakan secara manual, dimana pencatatan dan penyimpanan data ditulis di dalam buku, perhitungannya dikerjakan secara konvesional dengan menggunakan alat bantu kalkulator, dan data di simpan dalam bentuk arsip, dapat membuka peluang munculnya resiko hilangnya buku arsip akibat terkena air hujan, terbakar, dan lain-lain, atau yang lebih buruk lagi yaitu resiko pemalsuan data dari pihak tertentu yang mengakibatkan munculnya persengketaan dan perselisihan (Purnama, Kurniawati, \& Wahyudin, 2014, hlm. 1).

Selain itu, pendidikan menabung juga seyogyanya dilakukan dengan meminta anak agar menyisihkan uang sakunya ditabung (Rapih, 2016, hlm. 21). Sedangkan dalam kasus Rosita di atas, disebutkan bahwa tabungannya berasal dari pemberian orang tuanya. Tentu hal ini bertentangan dengan tujuan pendidikan menabung itu sendiri.

Berdasarkan permasalahan di atas, maka perlu diadakan penelitian yang melakukan peninjauan atas pelaksanaan upaya peningkatan literasi keuangan melalui tabungan siswa ini, untuk menemukan gambaran umum tentang bagaimana implementasinya saat ini di lapangan, sehingga dapat direncanakan tindakan evaluatif dalam rangka perbaikan pelaksanaan tabungan siswa tersebut. Sepengetahuan penyusun, penelitian yang menganalisa upaya peningkatan literasi keuangan melalui tabungan sekolah di wilayah Banjarmasin ini belum ada sebelumnya, sehingga perlu dilakukan agar pihak keluarga dan sekolah dapat memahami peran masing-masing dalam memberikan pendidikan literasi keuangan kepada anak, sehingga kasus seperti yang terjadi di SDN 1 Banjaratma di atas tidak terulang kembali.

Riset mengenai literasi keuangan atau literasi ekonomi yang dihubungkan dengan lembaga pendidikan sendiri sebenarnya sudah cukup banyak. (Permata, Wahyono, \& Wardoyo, 2017) misalnya, melakukan pengembangkan bahan ajar pada mata pelajaran IPS di sekolah dasar, dengan tambahan materi literasi ekonomi dalam bentuk cerita bergambar. Berdasarkan uji validitas untuk menguji kualitas bahan ajar yang telah disiapkan tersebut, ditemukan bahwa tingkat kevalidannya adalah sebesar 80,25\% sehingga bahan ajar tersebut masuk dalam kategori layak untuk digunakan. Kemudian dilakukan pula uji efektivitas dengan hasil 78,91\% meningkatkan motivasi belajar siswa, dan 75,35\% meningkatkan pemahaman siswa seputar literasi ekonomi, sehingga bahan ajar ini termasuk dalam kategori baik untuk diimplementasikan dalam pelaksanaan pembelajaran.

(Ilyana \& Sari, 2015) dalam risetnya juga melakukan pengembangkan media pembelajaran literasi keuangan berupa komik edukasi "Impian Moni" bagi siswa sekolah dasar. Pengembangan media pembelajaran dilakukan dengan metode Research and Development (R\&D) model FourD, yaitu Define, Design, Develop, dan Disseminate. Uji kelayakan dilakukan secara kuantitatif melalui penilaian ahli materi, 
media, dan bahasa dengan nilai rata-rata sebesar 4,26 (Sangat Layak), sedangkan uji efektivitas dilakukan berdasarkan gain peningkatan pemahaman siswa dengan hasil sebesar 0,37 (Sedang).

Kedua riset diatas mengembangkan media pembelajaran berupa buku cerita dan komik untuk meningkatkan literasi keuangan siswa sekolah dasar, sedangkan penelitian ini mengkaji bagaimana pelaksanaan tabungan siswa di sekolah dasar, mengidentifikasi kekurangan dan kelebihan tabungan siswa di setiap sekolah, dan merumuskan bentuk tabungan siswa yang ideal dalam upaya meningkatkan literasi keuangan pada siswa sekolah dasar tersebut.

\section{Metode}

Penelitian ini berjenis kualitatif lapangan yang disertai dengan survey kuantitatif untuk meneliti gejala suatu kelompok atau perilaku individu tertentu (Aprisya, Fauziah, \& Tresnati, 2015, hlm. 389). Maka dalam hal ini, gejala atau perilaku yang diteliti adalah pola menabung siswa, sedangkan kelompok yang diteliti adalah murid-murid sekolah dasar di wilayah kota Banjarmasin.

Populasi yang menjadi objek penelitian ini adalah siswa sekolah dasar di kota Banjarmasin, baik negeri maupun swasta. Berdasarkan data dari Badan Pusat Statistik Kota Banjarmasin jumlah siswa sekolah dasar yang secara kelembagaan berada di bawah Kementerian Pendidikan dan Kebudayaan, baik swasta maupun negeri adalah sebanyak 58.124 siswa, sedangkan jumlah siswa Madrasah Ibtidaiyah (MI) yang berada di bawah Kementerian Agama baik negeri maupun swasta adalah sebanyak 12.459 siswa (Badan Pusat Statistik Kota Banjarmasin, 2019, hlm. 101-102). Maka populasi total siswa tingkat sekolah dasar di Banjarmasin yaitu sebanyak 70.583 siswa. Selanjutnya untuk jumlah sampel ditentukan berdasarkan rumus Slovin dengan asumsi Margin of Error sebesar 5\% sebagaimana perhitungan berikut:

$$
n=\frac{N}{1+\left(N e^{2}\right)}=\frac{70583}{1+\left(70583 \times 0.05^{2}\right)}=397.76
$$

Dengan demikian, sampel minimal riset ini setelah dibulatkan adalah sebanyak 398 siswa. Adapun responden yang berhasil tim penulis peroleh adalah sebanyak 412 siswa, sehingga sudah memenuhi ketentuan sampel minimal tersebut. Kemudian untuk penentuan lokasi sampel ditentukan berdasarkan teknik purposive, dengan ketentuan sekolah tersebut harus memiliki tabungan sekolah. Tim penulis memilih metode tersebut karena responden dalam riset ini harus memiliki kriteria khusus, yaitu sekolahnya memiliki tabungan siswa, dan ia merupakan salah satu nasabahnya.

Data primer dikumpulkan dengan teknik wawancara yang direkam melalui media kuesioner. Wawancara dilakukan kepada dua pihak, yaitu sejumlah 412 siswa sebagai data utama yang tim penulis wawancarai satu per satu, dan perwakilan guru sebagai data tambahan untuk memperkuat kepercayaan terhadap data tersebut. Selain itu, data juga akan diperkuat melalui dokumentasi dan observasi. Dokumen yang diminta adalah fotokopi buku tabungan siswa, sedangkan observasi dilakukan pada saat siswa menyetorkan uang tabungan kepada pihak sekolah. Maka dengan triangulasi sumber data dan teknik pengumpulan ini diharapkan data dapat terjamin kebenarannya.

Model analisis yang digunakan dalam penelitan ini ada dua, yaitu metode survey kuantitatif untuk menganalisa pola menabung siswa dan model tabungan sekolahnya, serta analisa deskriptif kualitatif, untuk menganalisa kelebihan dan kekurangan tabungan siswa di setiap sekolah. Hasil analisa tersebut kemudian menjadi dasar penulis untuk merumuskan seperti apa tabungan sekolah yang ideal untuk memaksimalkan upaya literasi ekonomi di tingkat sekolah dasar.

\section{Hasil dan pembahasan}

Setiap responden dalam penelitian ini diberikan pertanyaan mengenai pola menabung mereka, apakah diambil dari uang saku sendiri, ataukah diberikan berbeda oleh orang tuanya. Selain itu, tim peneliti juga melayangkan pertanyaan kepada guru sekolah yang bersangkutan untuk memperkuat data tersebut, sekaligus menanyakan mengenai sistem tabungan di sekolahnya masing-masing apakah telah bekerjasama dengan lembaga perbankan ataukah hanya dikelola sendiri. Tim peneliti kemudian melakukan tabulasi data yang terangkum dalam tabel berikut: 
Tabel 1. Pola Menabung Siswa pada Sekolah Dasar di Kota Banjarmasin

\begin{tabular}{clcccl}
\hline No & \multicolumn{1}{c}{ Sekolah } & $\begin{array}{c}\text { Uang Saku } \\
\text { Sendiri }\end{array}$ & $\begin{array}{c}\text { Titipan } \\
\text { Orang Tua }\end{array}$ & $\begin{array}{c}\text { Kadang- } \\
\text { kadang }\end{array}$ & Kerjasama \\
\hline 1 & SDN Kebun Bunga 5 & 14 & 1 & 5 & Bank Kalsel \\
\hline 2 & SDN SN Kuripan 2 Banjarmasin & 13 & 6 & - & Bank Kalsel dan BRI \\
\hline 3 & SDIT Ukhuwah Banjarmasin & 33 & 19 & 3 & Bank Kalsel Syariah \\
\hline 4 & SDN SN Pemurus Baru 2 & 6 & 14 & - & - \\
\hline 5 & SDN Kertak Hanyar I-1 & - & 20 & - & - \\
\hline 6 & SDN Pangambangan 6 & 6 & 14 & - & - \\
\hline 7 & SD Muhammadiyah 6 & 6 & 19 & - & - \\
\hline 8 & SDN Pemurus Luar 1 & 2 & 18 & - & - \\
\hline 9 & SDN Kelayan Barat 2 & 2 & 18 & - & - \\
\hline 10 & SDN Pangambangan 5 & 4 & 16 & - & Bank Kalsel \\
\hline 11 & SDN SN Karang Mekar 1 & - & 20 & - & Bank Kalsel \\
\hline 12 & SDN Karang Mekar 9 & 13 & 2 & 5 & - \\
\hline 13 & SDN Kebun Bunga 3 & 3 & 17 & - & - \\
\hline 14 & SDN Pemurus Dalam 5 & 24 & - & - & Bank Kalsel \\
\hline 15 & SDN Kuin Selatan 1 & - & 20 & - & - \\
\hline 16 & MIN 3 Pemurus Dalam & 5 & 14 & 1 & - \\
\hline 17 & SDN Pekauman 2 & 5 & 15 & - & - \\
\hline 18 & SDN Pemurus Dalam 7 & $\mathbf{1 5 7}$ & $\mathbf{2 4 1}$ & $\mathbf{1 4}$ & Bank Kalsel \\
\hline & Jumlah & $\mathbf{3 8 . 1 \%}$ & $\mathbf{5 8 . 5 \%}$ & $\mathbf{3 . 4 \%}$ & $\mathbf{4 1 2}$ \\
\hline & Persentase & & & $\mathbf{1 0 0 \%}$ \\
\hline & Sum & & & \\
\hline
\end{tabular}

Sumber: Diolah Penulis, 2019

Tabel ini menunjukkan bahwa lebih dari setengah responden mengaku mendapatkan uang tambahan dari orang tuanya untuk keperluan menabung, dan hanya sekitar 38\% responden yang secara mandiri mengalokasikan sebagian uang sakunya untuk ditabung. Hal ini juga mungkin sejalan dengan hasil survei OJK sebelumnya, bahwa mayoritas masyarakat Banjarmasin sebenarnya secara sadar telah menggunakan layanan dari berbagai lembaga keuangan, namun tingkat pemahaman berikut keterampilan mereka terhadap keuangan itu sendiri masih cukup rendah. Pendidikan menabung seyogyanya dilakukan dengan meminta anak agar menyisihkan uang sakunya untuk ditabung (Rapih, 2016, hlm. 21), sedangkan pada praktiknya mayoritas tabungan responden berasal dari pemberian orang tuanya. Artinya, masih banyak orang tua siswa yang belum memahami dengan baik mengenai tujuan dari tabungan siswa tersebut.

Tabel di atas juga menunjukkan bahwa lebih dari setengah sekolah yang menjadi sampel penelitian (11 dari 18) mengelola tabungan siswanya secara mandiri tanpa melakukan kerjasama tertentu dengan lembaga perbankan. Pencatatannya pun masih dilakukan secara manual dimana pencatatan dan penyimpanan data ditulis secara sederhana melalui media buku tabungan atau Microsoft Excel.

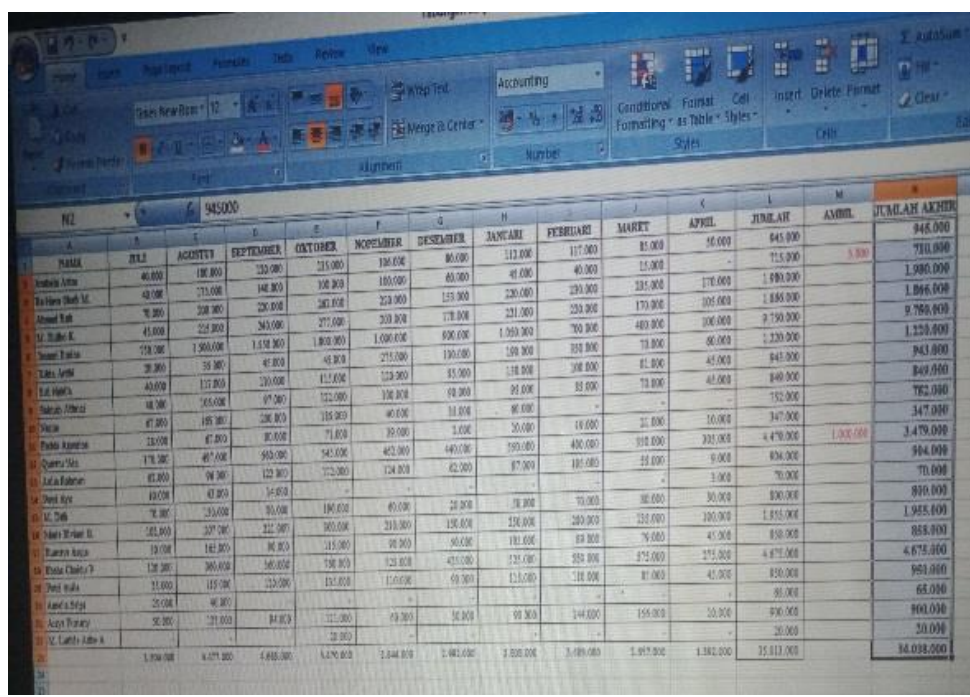

Gambar 1. Pencatatan tabungan siswa menggunakan Microsoft Excel pada salah satu sekolah yang menjadi sampel penelitian 
Pencatatan dengan cara manual, bahkan walaupun dengan memakai Microsoft Excel sekalipun, dapat membuka peluang munculnya resiko seperti hilangnya buku arsip ataupun kerusakan komputer akibat terkena air hujan, terbakar, dan lain-lain. Bahkan bisa juga muncul resiko yang lebih buruk lagi, yaitu pemalsuan data dari pihak tertentu, sehingga mengakibatkan munculnya persengketaan dan perselisihan (Purnama dkk., 2014, hlm. 1).

Selanjutnya, ada sekitar 40\% sekolah (7 dari 18) yang menjadi sampel riset telah melakukan kerjasama dengan lembaga perbankan, dan pencatatannya pun dilakukan dengan baik melalui media buku tabungan resmi dari bank berikut sistemnya. Apalagi bank umumnya memberikan imbal balik kepada nasabah penghimpunan dana dalam bentuk bonus untuk tabungan wadiah (Murdadi, 2016, hlm. 6), bagi hasil untuk tabungan mudharabah (Zaenudin, 2014, hlm. 71), dan bunga untuk tabungan konvensional (Heriberta, 2013, hlm. 122). Namun bank memiliki keterbatasan sumber daya untuk setiap hari mendatangi sekolah dan menghimpun dana siswa. Umumnya, bank hanya mampu berkunjung satu hingga dua kali per minggunya. Keterbatasan bank ini sangat berpengaruh besar terhadap intensitas menabung siswa.

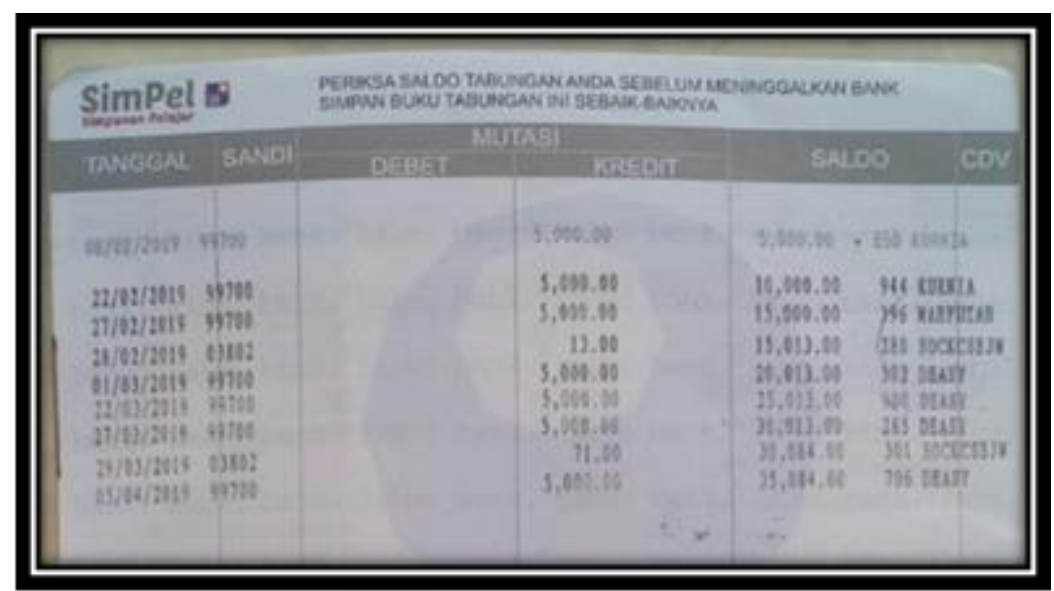

Gambar 2. Buku tabungan salah satu siswa yang sekolahnya sudah bekerjasama dengan bank. Terlihat bahwa intensitas menabungnya sangat sedikit, hanya tiga kali setiap bulannya.

Tabungan sekolah yang dikelola langsung oleh sekolahnya tidak mengalami masalah intensitas ini, sebab guru sekolah selalu ada dan siswa dapat menabung dengan bebas setiap harinya.

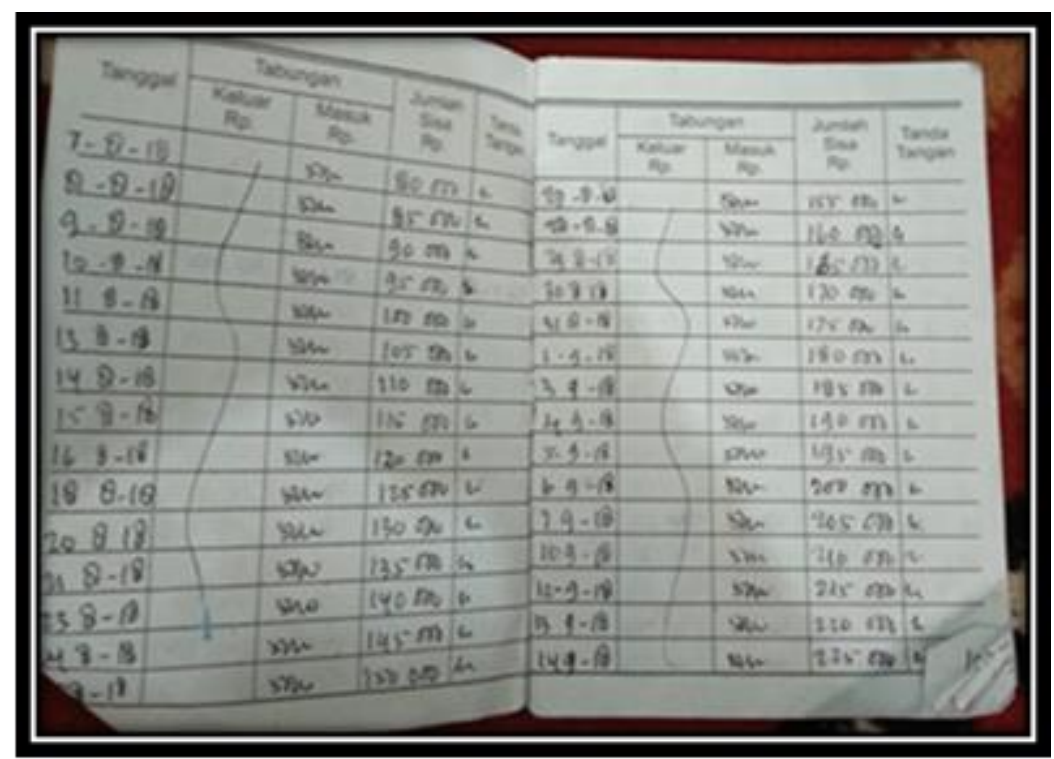

Gambar 3. Buku tabungan salah satu siswa yang belum bekerjasama dengan bank. Terlihat bahwa siswa tersebut menabung hampir setiap hari.

Temuan tim penulis ini sesuai dengan hasil riset (Perdana, 2018, hlm. 39) yang menyebutkan bahwa Bank Sumut Syariah Kantor Cabang Medan Brigjend Katamso hanya mampu mendatangi sekolah satu 
minggu sekali. Perdana juga menyebutkan kendala-kendala lainnya yang menjadi penghambat Bank Sumut Syariah dalam memasarkan produk Tabungan Simpelnya, yaitu sebagai berikut:

1. Waktu yang sempit, dimana pihak bank hanya mampu stand by beberapa jam saja di satu sekolah, karena dalam satu hari tersebut bank harus pergi ke beberapa sekolah yang lain.

2. Tidak dapat membuka tabungan apabila tidak ada Perjanjian Kerja Sama (PKS), yaitu bahwa jika sekolahnya belum atau tidak bekerja sama dengan pihak Bank Sumut Syariah, maka siswa/siswi nya tidak dapat membuka tabungan Simpel ini, sebab produk ini hanya bisa dibuka berdasarkan kerja sama pihak sekolah dengan bank.

3. Masyarakat belum memahami produk Tabungan Simpel, sebab produk Tabungan Simpel ini tergolong masih baru, sehingga masyarakat masih belum banyak mengetahui apalagi memahami konsep produk tersebut.

Fakta-fakta di atas menunjukkan bahwa setidaknya ada tiga problem utama yang harus dievaluasi untuk memaksimalkan pendidikan literasi ekonomi kepada siswa sekolah dasar melalui tabungan siswa. Ketiga masalah tersebut yaitu kecenderungan orang tua siswa untuk memberikan uang saku ditambah dengan uang tabungan kepada anaknya, sistem pencatatan manual yang rentan akan fraud pada tabungan siswa yang dikelola secara mandiri oleh sekolah, dan rendahnya intensitas menabung siswa pada tabungan siswa yang dikelola oleh perbankan. Oleh karena itu, peneliti akan menyampaikan berbagai tawaran solusi maupun saran bagi pihak-pihak yang berkepentingan dengan tabungan sekolah ini, yang bersumber dari riset-riset sebelumnya maupun gagasan tim penulis sendiri.

Pertama, orang tua ataupun wali siswa perlu mendapatkan pemahaman yang baik mengenai cara mengajarkan anaknya untuk menabung. Orang tua memiliki pengaruh yang besar terhadap tingkat literasi ekonomi anak-anaknya. (Wardani \& Qomariah, 2019, hlm. 115) melakukan analisis jalur untuk mengetahui pengaruh langsung dan tidak langsung orang tua dan guru terhadap metivasi menabung siswa tingkat sekolah dasar. Hasil riset ini menunjukkan bahwa pengaruh orang tua terhadap motivasi menabung pengaruh langsung memberikan nilai lebih tinggi dibandingkan pengaruh tidak langsung, bahwa siswa yang mendapatkan pengaruh dari orang tua memiliki motivasi menabung sebesar 8,36 kali dibandingkan orang tua yang tidak memberikan pengaruhnya. Sedangkan pengaruh langsung guru terhadap motivasi menabung siswa hampir sama dibandingkan pengaruh tidak langsung. Bahwa siswa yang diedukasi oleh guru hanya memiliki motivasi menabung sebesar 1,1702 kali lipat dibandingkan guru yang tidak mengedukasi siswanya. Hal ini menunjukkan bahwa pengaruh orang tua terhadap motivasi menabung siswa jauh lebih besar dibandingkan pengaruh guru ataupun sekolahnya.

Riset di atas diperkuat lagi oleh (Sirine \& Utami, 2016, hlm. 28) dengan objek yang berbeda, yaitu 221 mahasiswa Fakultas Ekonomi dan Bisnis Universitas Kristen Satya Wacana sebagai sampelnya. Hasil riset ini menunjukkan bahwa secara simultan faktor melek finansial, pengaruh orang tua, pengaruh rekan-rekan, dan kontrol diri memiliki pengaruh yang signifikan terhadap perilaku tabungan. Namun ketika dianalisis secara parsial, faktor melek finansial, faktor pengaruh orang tua, dan faktor kontrol diri memiliki pengaruh yang signifikan dan positif terhadap perilaku tabungan mahasiswa, sedangkan pengaruh rekan-rekan tidak berpengaruh secara signifikan. (Amilia, Bulan, \& Rizal, 2018, hlm. 105) dalam riset yang berbeda juga menyatakan bahwa nilai signifikan untuk variabel orang tua terhadap perilaku menabung mahasiswa Bidik Misi Fakultas Ekonomi Universitas Samudra adalah sebesar 0,000 < alpha 0,05. Artinya, variabel orang tua berpengaruh signifikan terhadap perilaku menabung ini. Orang tua berperan langsung dan menjadi panutan dalam perkembangan keuangan anak mereka. Jika seorang anak tidak mendapatkan pendidikan keuangan yang baik dalam keluarga, maka anak akan cenderung tidak bisa mengelola keuangan pribadinya dengan baik hingga berdampak pada perilaku menabungnya.

Kedua, pencatatan tabungan siswa harus dibantu oleh sistem yang dapat dipantau oleh guru, siswa, dan wali muridnya untuk memperkecil kemungkinan terjadinya fraud. Fraud sendiri merupakan tindakan kecurangan dalam suatu transaksi bisnis yang disengaja sehingga dapat menimbulkan kerugian (Wijaya, Yuniarta, \& Sujana, 2018). Mengenai hal ini, telah banyak penelitian yang mencoba berkontribusi untuk memudahkan sekolah dalam melakukan pendataan tabungan sekolah tersebut.

(Nisa, Kurniawan, \& Sari, 2017, hlm. 1481) mengembangkan program komputer dengan fitur SMS Gateway yang dirancang untuk membantu sekolah dalam melakukan pendataan SPP dan tabungan sekolah. Aplikasi ini juga dilengkapi dengan fitur SMS Gateway untuk mempermudah sekaligus mempercepat penyampaian informasi kepada orang tua siswa mengenai pembayaran SPP, penambahan saldo tabungan, hingga penarikan saldo tabungan yang dimiliki oleh anaknya masing-masing. MTS dan MA Mathla'ul Huda menjadi pilot project yang bersedia menggunakan sistem tersebut

Pencatatan transaksi tabungan menggunakan sistem berbasis web seperti yang ditawarkan oleh riset di atas akan mempermudah sekolah dalam mengarsipkan data tabungan siswa sekaligus mengurangi resiko terjadinya fraud. Masih banyak lagi riset yang menawarkan hal serupa selain contoh tersebut, terutama dari akademisi program studi Teknik Informatika. Sekolah yang memerlukan sistem seperti ini hanya perlu 
menghubungi tim penulis riset-riset tersebut melalui e-mail ataupun kontak lainnya yang tersedia di identitas penulisnya.

Kemudian untuk problem ketiga, sekolah dapat mengkombinasikan antara tabungan dengan pengelolaan mandiri dan tabungan yang dikelola lembaga perbankan. Caranya yaitu dengan tetap menerima setoran tabungan siswa setiap harinya dengan pencatatan berbasis sistem web, untuk kemudian dikumpulkan dan disetorkan sekaligus kepada bank pada saat bank tersebut melakukan kunjungan ke sekolah.

Pada akhirnya, diperlukan kerjasama yang intens antara orang tua siswa, sekolah, dan lembaga perbankan untuk mewujudkan tabungan sekolah yang ideal. Orang tua perlu memahami konsep tabungan sekolah dan kemudian memotivasi anaknya agar menyisihkan sebagian uang sakunya untuk ditabung, sekolah perlu menyediakan sarana dan sumber daya yang layak untuk menangani tabungan tersebut, dan lembaga perbankan perlu menyediakan produk yang menarik berikut perangkatnya untuk mempermudah sekaligus memperbesar minat siswa untuk menabung.

\section{Simpulan dan saran}

Temuan di atas menunjukkan bahwa 58,5\% responden mendapatkan uang tambahan dari orang tuanya untuk keperluan menabung, dan hanya $38,1 \%$ responden yang secara mandiri mengalokasikan sebagian uang sakunya untuk ditabung. Berikutnya 11 dari 18 sekolah yang menjadi lokasi riset mengelola tabungan siswanya secara mandiri dengan metode pencatatan secara manual dan sederhana melalui media buku tabungan atau Microsoft Excel, sedangkan tujuh sekolah lainnya telah melakukan kerjasama dengan lembaga perbankan, namun bank hanya mampu berkunjung satu hingga dua kali per minggunya sehingga mengurangi intensitas menabung siswa.

Tim penulis menawarkan tiga solusi untuk untuk memaksimalkan potensi pendidikan literasi ekonomi kepada siswa sekolah dasar melalui tabungan sekolah. Pertama, orang tua ataupun wali siswa perlu mendapatkan pemahaman yang baik mengenai cara mengajarkan anaknya untuk menabung. Sekolah dapat menyampaikan pentingnya pemahaman orang tua ini dalam forum pertemuan antara guru dengan orang tua murid, atau melalui grup Whatsapp, Channel Telegram, dan media sejenisnya. Kedua, pencatatan tabungan siswa harus dibantu oleh sistem yang dapat dipantau oleh guru, siswa, dan wali muridnya untuk memperkecil kemungkinan terjadinya fraud. Ketiga, jika sekolah telah memiliki kerjasama dengan lembaga perbankan, sekolah dapat mengkombinasikan antara tabungan dengan pengelolaan mandiri dan tabungan yang dikelola lembaga perbankan, yaitu dengan tetap menerima setoran tabungan siswa setiap harinya dengan pencatatan berbasis sistem web, untuk kemudian dikumpulkan dan disetorkan sekaligus kepada bank pada saat bank tersebut melakukan kunjungan ke sekolah.

Penelitian ini menggunakan metode purposive dalam menentukan lokasi sampelnya, oleh karena itu hasil survey tidak bisa diuji signifikansinya kepada keseluruhan populasi. Metode ini terpaksa digunakan karena tim peneliti tidak menemukan data pasti mengenai jumlah sekolah dasar di Banjarmasin yang memiliki tabungan sekolah, berikut data siswa yang menabung. Berdasarkan hal tersebut, tim penulis berkeyakinan bahwa peluang pengembangan riset ini masih sangat besar. Jika data sekolah dasar yang memiliki tabungan sekolah serta data populasi nasabahnya telah diketahui, peneliti selanjutnya dapat melakukan pemilihan sampel dengan menggunakan metode cluster sampling yang memiliki akurasi lebih baik dan dapat diuji signifikansinya. Selain itu, peneliti selanjutnya juga dapat melakukan riset R\&D (Research and Development) untuk menguji kelayakan dan efektivitas model tabungan sekolah yang ditawarkan dalam penelitian ini, sekaligus melakukan kegiatan PKM (Pengabdian kepada Masyarakat) kepada sekolah eksperimen.

\section{Daftar Rujukan}

Affan, H. (2016). Mengapa Dimas Kanjeng Mampu Himpun Ribuan Anggota? Diambil 28 Agustus 2018, dari BBC News Indonesia website: https://www.bbc.co.uk/indonesia/berita_indonesia/2016/10/161003_indonesia_dimaskanjeng

Amilia, S., Bulan, T. P. L., \& Rizal, M. (2018). Pengaruh Melek Finansial, Sosialisasi Orang Tua, dan Teman Sebaya Terhadap Perilaku Menabung Mahasiswa Bidik Misi Fakultas Ekonomi Universitas Samudra. Jurnal Samudra Ekonomika, 2(2), 97-107. https://doi.org/10.1234/jse.v2i2.877

Aminudin, M. (2017). Kisah Rosita dan Uang Tabungan Rp 42 Juta yang Tak Diakui Sekolah. Diambil 28 Agustus 2018, dari Detiknews website: 
https://news.detik.com/read/2017/06/20/163719/3536852/475/kisah-rosita-dan-uangtabungan-rp-42-juta-yang-tak-diakui-sekolah

Aprisya, R., Fauziah, E., \& Tresnati, R. (2015). Pengaruh Pelayanan Prima (Service of Excellence) Terhadap Kepuasan Pelanggan (Survey Nasabah Bank Danamon Syariah KCP Pungkur Bandung). Prosiding Keuangan dan Perbankan Syariah, 1, 389-396. Universitas Islam Bandung. Diambil dari http://karyailmiah.unisba.ac.id/index.php/hukum_ekonomi_syariah/article/view/1207

Astuti, E. D. (2013). Perilaku Konsumtif dalam Membeli Barang pada Ibu Rumah Tangga di Kota Samarinda. eJournal Psikologi, 1(2), 148-156.

Badan Pusat Statistik Kota Banjarmasin. (2019). Kota Banjarmasin dalam Angka 2019. Diambil dari https://banjarmasinkota.bps.go.id/publication/2019/08/16/aa133421b5424804385f0b58/kotabanjarmasin-dalam-angka-2019.html

detiknews. (2012). Merasa Ditipu MLM Langit Biru, Ratusan Orang Jarah Sabun dan Beras. Diambil 28 Agustus 2018, dari Detiknews website: https://news.detik.com/read/2012/06/02/145911/1931133/10/merasa-ditipu-mlm-langit-biruratusan-orang-jarah-sabun-dan-beras

Hambali, G. (2016). Literasi Ekonomi di Sekolah. Jurnal Scientium, 3(5), 43-53.

Herawati, N. T. (2015). Kontribusi Pembelajaran di Perguruan Tinggi dan Literasi Keuangan terhadap Perilaku Keuangan Mahasiswa. Jurnal Pendidikan Dan Pengajaran, 48(1-3). Diambil dari https://ejournal.undiksha.ac.id/index.php/JPP/article/view/6919

Heriberta. (2013). Perbedaan Perilaku Tabungan Masyarakat di Pulau Sumatera. Jurnal Perspektif Pembiayaan Dan Pembangunan Daerah, 1(2), 121-126.

Ilyana, S., \& Sari, R. C. (2015). Pengembangan Komik Edukasi Sebagai Media Pembelajaran Literasi Keuangan untuk Siswa Sekolah Dasar. Jurnal Pendidikan Akuntansi Indonesia, 13(2), 58-70.

Laily, N. (2016). Pengaruh Literasi Keuangan terhadap Perilaku Mahasiswa dalam Mengelola Keuangan. Journal of Accounting and Business Education, 1(4). Diambil dari http://journal.um.ac.id/index.php/jabe/article/view/6042

Ma'ruf, A. A., Zulfiah Larisu, \& La Iba. (2017). Teknik Komunikasi PT. Bank Sultra Kantor Kas Baruga dalam Pengenalan Menabung Sejak Dini pada Anak Sekolah Menengah Pertama di Kota Kendari. Journal Ilmu KOMUNIKASI UHO, 2(2). Diambil dari http://ojs.uho.ac.id/index.php/KOMUNIKASI/article/view/2513

Mohamad, A. (2012). Koperasi Tawarkan Keuntungan di Atas BI Rate Pasti Penipuan. Diambil 28 Agustus 2018, dari Merdeka.com website: https://www.merdeka.com/uang/koperasi-tawarkankeuntungan-di-atas-bi-rate-pasti-penipuan.html

Murdadi, B. (2016). Menguji Kesyariahan Akad Wadiah pada Produk Bank Syariah. VALUE ADDED / $\begin{array}{lllll}M A J A L A H & \text { EKONOMI } & \text { DISNIS, } & \text { Diambil } & \text { dari }\end{array}$ https://jurnal.unimus.ac.id/index.php/vadded/article/view/2940

Nisa, J. C., Kurniawan, A. P., \& Sari, S. K. (2017). Aplikasi Pembayaran SPP dan Saldo Tabungan Berbasis Web Disertai SMS Gateway (Studi Kasus: MTS dan MA Mathla'ul Huda). eProceedings of Applied Science, 3. Diambil https://libraryeproceeding.telkomuniversity.ac.id/index.php/appliedscience/article/view/5309

Perdana, S. (2018). Strategi Pemasaran Produk Tabungan Simpel Pada PT. Bank Sumut Syariah Kantor Cabang Medan Brigjend Katamso (Universitas Islam Negeri Sumatera Utara). Universitas Islam Negeri Sumatera Utara, Medan. Diambil dari http://repository.uinsu.ac.id/4336/1/SKRIPSI.pdf

Permata, B., Wahyono, H., \& Wardoyo, C. (2017). Bahan Ajar Berbasis Cerita untuk Menanamkan Literasi Ekonomi pada Siswa Sekolah Dasar. Jurnal Pendidikan, 2(3), 356-362.

Purnama, H., Kurniawati, R., \& Wahyudin, W. (2014). Perancangan Program Aplikasi Tabungan Siswa Sekolah Dasar Negeri Cipancar IV dengan Menggunakan Pendekatan Metodologi Rapid Application Development. Jurnal Algoritma, 11(1), 7.

Putri, S. A. (2017). Pengaruh Norma Subyektif, Religiusitas dan Self Control terhadap Perilaku Konsumtif Masyarakat Muslimah Pengguna Kartu Kredit (UIN Sunan Ampel Surabaya). UIN Sunan Ampel Surabaya. http://digilib.uinsby.ac.id/20696/10/Daftar\%20Pustaka.pdf

Rapih, S. (2016). Pendidikan Literasi Keuangan pada Anak: Mengapa dan Bagaimana? Scholaria: Jurnal Pendidikan Dan Kebudayaan, 6(2), 14-28. https://doi.org/10.24246/j.scholaria.2016.v6.i2.p14-28

Sirine, H., \& Utami, D. S. (2016). Faktor-Faktor Yang Memengaruhi Perilaku Menabung Di Kalangan Mahasiswa. Jurnal Ekonomi dan Bisnis, 19(1), 27-52. https://doi.org/10.24914/jeb.v19i1.479

Sriono. (2017). Sistem Pewarisan pada Warga Negara Indonesia Keturunan Tionghoa (Cina) Muslim. Jurnal $\begin{array}{llll}\text { Ilmiah Advokasi, } & \text { 5(2). Diambil dari }\end{array}$ http://jurnal.stihlabuhanbatu.ac.id/index.php/ADVOKASI/article/view/82 
Suripto, I. (2020, Mei 4). Guru di Brebes Bobol Ruko demi Mengganti Tabungan Siswa yang Ditilap. Diambil 28 Mei 2021, dari Detiknews website: https://news.detik.com/berita-jawa-tengah/d5001277/guru-di-brebes-bobol-ruko-demi-mengganti-tabungan-siswa-yang-ditilap

Wardani, D. K., \& Qomariah, U. K. N. (2019). Analisis Jalur Faktor yang Mempengaruhi Motivasi Menabung Siswa Sekolah Dasar. Exact Papers in Compilation (EPiC), 1(3), 115-122.

Wijaya, I. G. N. A., Yuniarta, S. E. A. G. A., \& Sujana, E. (2018). Pengaruh Keadilan Distributif, Efektivitas Sistem Pengendalian Internal, dan Moralitas Individu Terhadap Kecenderungan Fraud pada Tabungan Siswa (Studi pada Sekolah Dasar di Kabupaten Buleleng). JIMAT (Jurnal Ilmiah Mahasiswa Akuntansi) Undiksha, 8(2). https://doi.org/10.23887/jimat.v8i2.14468

Wijayanti, Agustin, G., \& Rahmawati, F. (2016). Pengaruh Jenis Kelamin, IPK, dan Semester terhadap Literasi Keuangan Mahasiswa Prodi S1 Ekonomi Pembangunan Universitas Negeri Malang. Jurnal Pendidikan Ekonomi, 9(1). Diambil dari http://journal2.um.ac.id/index.php/jpe/article/view/1625

Zaenudin. (2014). Pengaruh Pendapatan Bagi Hasil Mudharabah, Musyarakah dan Murabahah Terhadap Bagi Hasil Tabungan (Studi Pada KSU BMT Taman Surga Jakarta). ETIKONOMI, 13(1). https://doi.org/10.15408/etk.v13i1.1879 